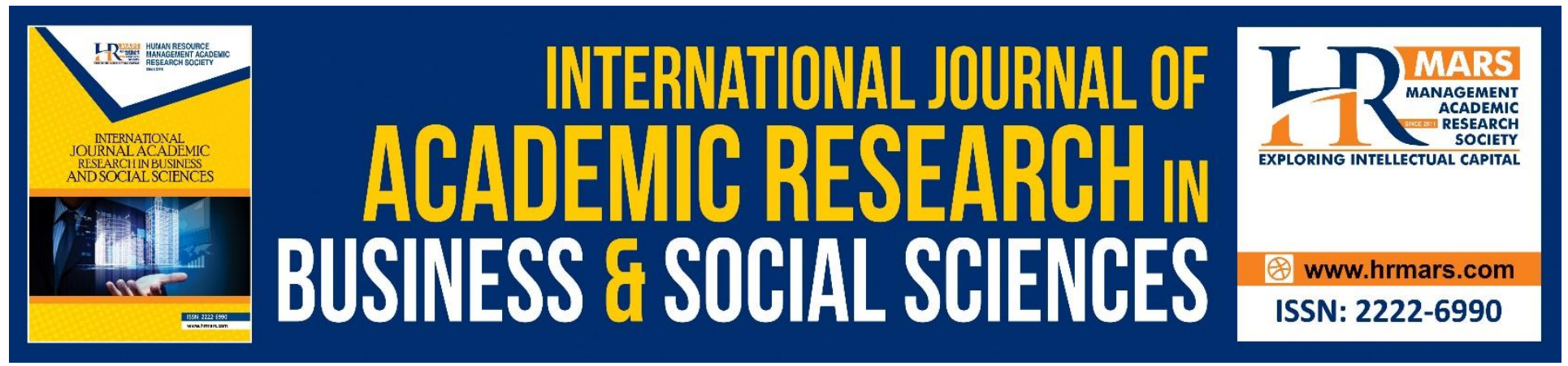

\title{
The Role of Tasawwuf Ulama in the Governance of Aceh
}

Yulisman Nazim, Mohamad Zaidin Mohamad, Omar S.H.S., Wan Ismail Wan Abdullah, Engku Ibrahim Engku Wok Zin, Sofyuddin Yusof, Afriani Maifizar, Fajri M Kasim

To Link this Article: http://dx.doi.org/10.6007/IJARBSS/v8-i10/4746

DOI: $10.6007 /$ IJARBSS/v8-i10/4746

Received: 26 Sept 2018, Revised: 24 Oct 2018, Accepted: 28 Oct 2018

Published Online: 31 October 2018

In-Text Citation: (Nazim et al., 2018)

To Cite this Article: Nazim, Y., Mohamad, M. Z., S.H.S., O., Abdullah, W. I. W., Zin, E. I. E. W., Yusof, S., ... Kasim, F. M. (2018). The Role of Tasawwuf Ulama in the Governance of Aceh. International Journal of Academic Research in Business and Social Sciences, 8(10), 437-448.

Copyright: (C) 2018 The Author(s)

Published by Human Resource Management Academic Research Society (www.hrmars.com)

This article is published under the Creative Commons Attribution (CC BY 4.0) license. Anyone may reproduce, distribute, translate and create derivative works of this article (for both commercial and non-commercial purposes), subject to full attribution to the original publication and authors. The full terms of this license may be seen at: http://creativecommons.org/licences/by/4.0/legalcode

Vol. 8, No. 10, 2018, Pg. 437 - 448

http://hrmars.com/index.php/pages/detail/IJARBSS

JOURNAL HOMEPAGE

Full Terms \& Conditions of access and use can be found at http://hrmars.com/index.php/pages/detail/publication-ethics 


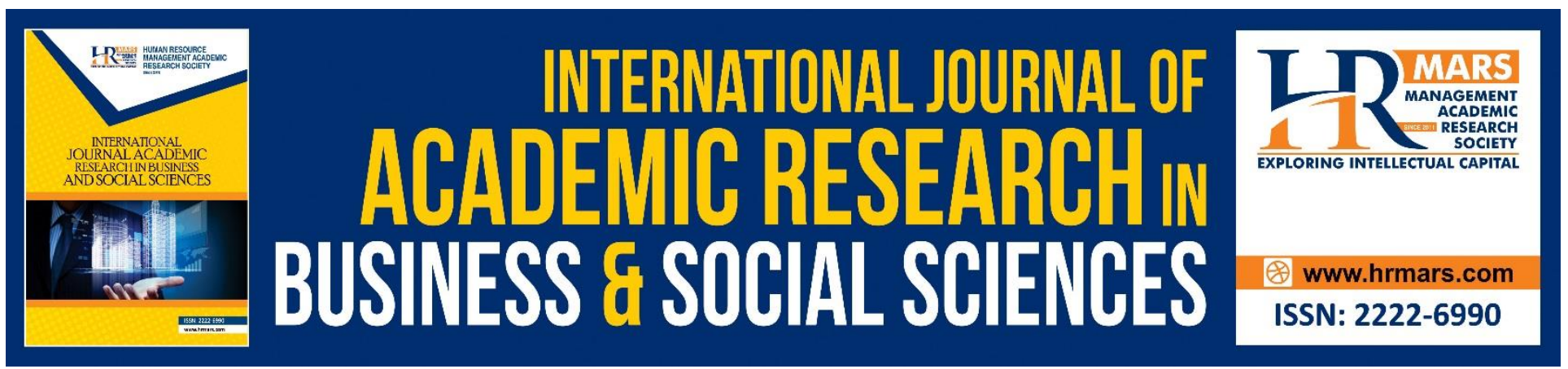

\title{
The Role of Tasawwuf Ulama in the Governance of Aceh
}

\author{
${ }^{1}$ Yulisman Nazim, ${ }^{1}$ Mohamad Zaidin Mohamad ${ }^{*},{ }^{1}$ Omar S.H.S., \\ ${ }^{1}$ Wan Ismail Wan Abdullah, ${ }^{1}$ Engku Ibrahim Engku Wok Zin, \\ ${ }^{1}$ Sofyuddin Yusof, ${ }^{2}$ Afriani Maifizar, ${ }^{3}$ Fajri M Kasim \\ ${ }^{1}$ Faculty of Islamic Contemporary Studies, UniSZA, Malaysia \\ ${ }^{2}$ Faculty of Social and Political Science, Universitas Teuku Umar, Aceh \\ ${ }^{3}$ Faculty of Social and Political Science, Universitas Malikussaleh, Aceh \\ *Corresponding Author : mzaidin@unisza.edu.my
}

\begin{abstract}
History has recorded a great contribution of tasawwuf ulama towards the arrival and development of Islam in the archipelago, especially in Aceh. However, their contributions and roles, particularly for the government are rarely highlighted. Hence this article aims to analyze the role of tasawwuf ulama in assisting the governance of Aceh into a sovereign government and loved by its people. This article is qualitative with documentation design. Data collection is through primary and secondary sources that related to the title. The data obtained are analyzed by content analysis and deduction. This article clearly demonstrates the role of tasawwuf ulama in the government by acting as an adviser, diplomatic and mufti. This study contributes to the purification of understanding and perception of the great contribution of tasawwuf ulama in Aceh.
\end{abstract}

Keywords: Tasawwuf, Governance, Aceh

\section{INTRODUCTION}

According to Nasr and Smith, "Islam is not only a religion; it is also the creator and living spirit of major world civilization with a long history stretching over fourteen centuries". Contemporary orientalist Bernard Lewis stated that "Islam, the offspring of Arabia and the Arabian Prophet, was not only a system of beliefs and a cult. It was also a system of state, society, law, thought and art as well as a civilization with religion as its unifying element and eventually, a dominating factor". This means that Islam and civilization are inseparable. Since coming into existence, Islam has introduced a concept and a mission pertaining to civilization because the system introduced by Islam patronizes the happiness of the individual and society. It would not be something strange if Islamic civilization cannot be isolated from its spiritual component, which is Islam. With Islam being the al-din and al- 
INTERNATIONAL JOURNAL OF ACADEMIC RESEARCH IN BUSINESS AND SOCIAL SCIENCES Vol. 8, No. 10, Oct. 2018, E-ISSN: 2222-6990 @ 2018 HRMARS

madaniyah or al-hadarah (civilization), hence, the meaning, concept, characteristics and contributions of Islamic civilization towards humans and humanity is quite evident (Qosim, 2015).

The rise of Madinah is proof of the statement above. This was the success of Prophet Muhammad SAW in developing a social order that was fair, peaceful and civilised. That success was the pride and source of inspiration for Muslims until today. Madinah was a symbol of victory invigorated the value of unity and pride among Muslims. Madinah was not only occupied by Muslims but occupants of other religions as well, such as the Jews, whose safety was guaranteed according to the al-Sahifah or the "Madinah Charter" (Pulungan, 1995).

After the demise of Prophet Muhammad SAW, those who carried on the message of Islam were the Ulama. A popular hadith of the Prophet SAW states that the Ulama are heir to the Prophets (al-ulama' warathah al-anbiya'); hence, they are highly respected by the Muslimin. Their opinions are presumed to be deciding factors in various problems, not only limited to religious problems only but various other problems. Nikkie R Kiddie in her book "Scholar, Saint and Sufis: Muslim Religious Institution in the Middle East since 1500", defined the Ulama as a group of powerful and respected people that has a big impact on building the Muslim society. Ulama who carry out their duties as teachers, religious orators receive acknowledgement in various forms based on their services. They also manage organizations related to education, the courts, hospitals as well as other charitable organizations. The authority of the Ulama is not only related to problems pertaining to Islamic law and education but also in other matters (TriPutra, 2015).

The Ulama have a unique way in building a relationship with Rulers. They are not reticent in criticizing the actions of Rulers that contradict Islamic teachings. One example is the initiative taken by the tasawwuf scholar Imam al-Hasan al-Basri and his followers on the Umayyah Ruler who acted according to his natural instincts (hawa nafsu). The Imam's criticisms were aimed at reproaching and improving governance (Rahman, 1984: 185). Imam al-Ghazali, in his book "Ihya' "Ulum al-Din", had also advised the Ruler to be cautious with the trust inherent in a leadership. It was this opinion held by Imam al-Ghazali that lead to his apprehension that every Ruler was infected with the Pharaoh's predicament, which was the greed for power to compete with God (Abidin, 1975).

The Ulama's criticisms and rapprochement towards Rulers were a "golden achievement" in Islamic history. Not all of these actions received a negative response from the Rulers. For example, when Baghdad and Khurasan were under the control of the Saljuq Dynasty, Imam al-Ghazali, who was famous for his reservoir of knowledge, was invited by the government and rewarded with a special position within the government (Hidayat, 2017).

\section{AS AN ADVISOR}

Islamic philosophy states that one of the factors that determines whether a country achieves "Baldatun tayyibatun wa rabbun ghafur" is the cooperation between the ulama and the umara (rulers). The reminder lies in a hadith narrated by Imam Abu Nu'aym al-AîfahÉni in the Hilyat alAwliya' scripture, meaning: "There are two types of people, if both are good than humankind would 
INTERNATIONAL JOURNAL OF ACADEMIC RESEARCH IN BUSINESS AND SOCIAL SCIENCES Vol. 8, No. 10, Oct. 2018, E-ISSN: 2222-6990 @ 2018 HRMARS

be good and if both are depraved, then humankind would be depraved as well, that is the ulama and umara". This reminder that is 14 centuries old should be considered by the Ulama and umara at all times because the reality in society reflects the truth of the hadith (Nasar, 1996).

The success of a government heavily depends on the type of government initiated by the Ruler. The King holds the main position in a government and an important one, which is the focus of the whole leadership under his command. Nevertheless, the King is not a figure who is able to address or administer all the duties in a government. Surely the King would need the assistance of others who are able and qualified in their respective fields. Besides that, the King would need an advisor to accompany him when deciding on certain matters, especially on matters related to religion and the spiritual development of society. In such a situation, the King needs someone who is wise and sincere. Hence, the Ulama are the correct persons to fulfil the above criteria (Gazali, 2016).

Since the beginning of Islamic rule in Samudera Pasai, Islamic knowledge started to expand all over the Malay Archipelago. As noted by Ibn Batutah, who visited Pasai in 1345/1346, Sultan alMalik al-Zahir (the eldest Prince of Sultan Malik al-Salih) loved religion and was close to the Ulama and fuqaha, who mainly came from Iran (Parsi). Besides that, several famous Ulama were chosen as advisors to the Sultan and his Princes (Said, 1981).

One of the Ulama who was appointed as an advisor was al-Shaykh Isma'il. Some believe that he was instructed by the Sharif of Mecca to go to Samudera and propagate Islam (Ayang, 2015, 275). In addition, it was recorded in Hikayat Raja-raja Pasai that he was a Ulama from the Sufi sect originating from Mecca and went to Samudera Pasai to propagate Islam. He had succeeded in convincing Raja Samudera to embrace Islam and was named Merah Silu, who then used the honorific al-Malik al-Salih. This shows that among the strategies used by the tasawwuf Ulama to propagate Islam in a particular area was to approach the local leaders and forge a harmonious relationship with the society there. Finally, Islam was easily accepted by the people because their leaders had initially embraced Islam (Rahayu, 2015).

Aceh, an Islamic-ruled territory in the Malay Archipelago, had since the fall of Melaka in $1511 \mathrm{M}$, significantly contributed to the development and progress of the Islamic civilization in this region. This territory not only played a role in the national socio-political scene but also as a prominent centre for Islamic civilization and studies. Political literature concerning Malay grassroots emerged gradually, as in Taj al-Salatin (1603/1604) by Bukhari Jawhari, Sulalat al-Salatin (1612-1617) by Tun Seri Lanang and Bustan al-Salatin (1638-1641) by Nuruddin Raniri, which were filled with knowledge on leadership from an Islamic perspective (Shahrul, 2012).

The Taj al-Salatin scripture, for example, emerged due to the political turmoil in the Aceh Dar al-Salam government. According to Prof. Abdul Hadi (2015: 1), Bukhari Jawhari was a tasawwuf Ulama because there were Sufi moral values in his literary works. His scripture was meant for Sultan 'Alauddin Ri'ayat Shah Sayyid al-Mukammil (1590-1604M) as a contribution by a Ulama in the form of an advice to the Sultan in carrying out his rule according to tenets of the al-Qur'an and al-Sunnah. 
According to Raden Hoesein Djajadiningrat, when the scripture was written, Aceh was involved in a political turmoil and leadership crises. Siddiq Fadzil agreed with this theory because according to him a poetry by Hamzah Fansuri had expressed dissatisfaction towards the political behaviour of the Aceh rulers, the nobilities and dignitaries who were greedy and cruel (Shahrul, 2014).

In the history of the Aceh Dar al-Salam government since its inception, every Sultan was accompanied by an Ulama as an advisor, educator, a guide for the Sultan and dignitaries besides being a reference for solving problems related to governance, writing codes of law (government policies) that determine the direction of the government's rule and as a mode to deliver the government's wishes and information to the people. For example, Sheikh 'Abd Allah Kan'an was a teacher, advisor and educator to Meurah Johan, Sultan to the Government of Aceh Dar al-Salam and its dignitaries. Centred in his zawiyah (religious school) in Lam Keuneu'en, he not only guided the Royalty in the palace but also the community in Kampung Lamuri that had recently embraced Islam (Abdullah, 2008).

Moving into the $17^{\text {th }}$ century brought change to the role of the Ulama in the government. They were not only skilled in religious matters but also capable of discussing matters related to political or national importance. These expert capabilities had further strengthened the Ruler's trust in them. Thus, a combination of the mastery of religious knowledge and administration had influenced the Rulers to obtain their advice and this kind of a situation had become common back then (Gazali, 2016).

One example was during the reign of Sultan Iskandar Muda as the leader of the Aceh Dar al-Salam government, when the scholar who was his advisor was Sheikh Shamsuddin Sumatrani. According to Hikayat Aceh, the position of the Sultan's advisor held by Sheikh Shamsuddin not as a gift from Sultan Iskandar Muda (who ruled from 1606 to 1636) but because he was highly knowledgeable (Suwondo, 1998).

According to Bukhari Jawhari in his scripture Taj al-Salatin, the Sultans of Aceh not only obtained advice from the Ulama but some of them practiced tarekat and performed the zikir together with the people. This influenced their soul to like listening to advice and not be afraid of dying. The climax of their practices was in 1629, when the bravest and biggest Acehnese army and armada headed by Sultan Iskandar Muda and Sheikh Shamsuddin Sumatrani had tried to free Melaka from the Portuguese. This effort failed with the death of many Acehnese soldiers, including Shamsuddin Sumatrani. After that defeat, the strength of the Acehnese armada in the Melaka Straits became weak. However, the combination involving the leaders and ulama in administrating the country was further substantiated by Sultan Iskandar Muda, which took Aceh to the pinnacle of success and excellence throughout his reign (Shahrul, 2014).

When Sheikh Nuruddin Raniri was in Aceh he was appointed as the "Sheikh al-Islam of the Sultanate". Among his duties was to offer advice to Sultan Iskandar Thani, who had just ascended the throne, on various issues, either religious or political. In Bustan al-Salatin, he elaborated on how to 
advice the Sultan, who was the controller and khalifah of Allah on this earth. By quoting verses of the al-Qur'an, he explained to the Sultan about his responsibilities and obligations to the people. Protecting the weak and bringing goodwill to the people would provide the Sultan protection and blessings from Allah. Perhaps due to his advice, Sultan Iskandar Thani had abolished punishments for crimes that were not consistent with Islamic teachings, such as immersing one's hand into hot oil (meresap minyak) or licking a hot piece of iron (menjilat besi) (Majid, 2015).

Since the era of Sultan Sayyid al-Mukammil, who was close to Hamzah Fansuri, the various Sultans of Aceh were known to be close to the Ulama. For example, Sultan Iskandar Muda was close to Shamsuddin Sumatrani, Sultan Iskandar Thani was very close to Sheikh Nuruddin Raniri and Sheikh 'Abdurrauf Singkili was known to be the advisor for four Sultanahs who ruled Aceh for 59 years. Sheikh Jalaluddin Tursani, an Ulama as well as a student of Sheikh 'Abdurrauf Singkili, was chosen to become the Qadi al-Malik al'Adil in two eras of rule, namely at the helm of Sultan 'Alauddin Maharajalela Ahmad (1727-1736) and Sultan 'Alauddin Johan Shah (1736-1760) (Shahrul, 2014).

Lately though, the roles of Acehnese Ulama have been combined into one entity or a gathering known as "Majelis Permusyawaratan Ulama" (MPU). This gathering was an institution that was formed after instilling a special kind of autonomy followed by implementing Syariat Islam in Aceh. MPU represents the institution of the Ulama, which is influential and legitimised in the Acehnese society. One of the duties of MPU is to offer advice to the Ruler as mentioned in the Qanun Aceh Nombor 2 Tahun 2009. Most of the members of MPU are Ulama who focus on Islamic knowledge in a general sense while some practice the teachings of tasawwuf.

Although now there was the gathering of MPU in Aceh, however, personal visits by Acehnese leaders to meet the Ulama still had a big influence among the Acehnese society. For example, Irwandi Yusuf, the Governor of Aceh, had visited Teungku Mulammad Amin Mahmud or known as Abu Tu Min, to seek advice from the Ulama, who was also a member of the Tarekat Haddadiyyah (Hasan, 2017).

\section{AS A DIPLOMAT}

The word 'diplomat' has Latin and Greek origins and could be defined as a symbol of qualification. The term 'diplomacy' then manifests itself in 'diplomat', diplomacy' and 'diplomatic' (Kansil, 2008). According to Sumaryo Suryokusumo, 'diplomacy' refers to political activities and is part of international activities that are influential and complex, which involves the government and international organizations, in order to achieve its objectives through diplomatic representation or other organizations (Suryo, 2008). Diplomatic relations originated from the existence of culture (customs) that was evident far earlier than the countries around the world knew about diplomatic structures like today. This had occurred since the time of Ancient India and was referred by the term "ambassador". This relationship occurred between the King and the government (Widagdo, 2008).

In the $16^{\text {th }}$ century, Aceh became a very important government in the Malay Archipelago and had political as well as diplomatic influence on the international world, such as with the 'Ottoman 
Caliphate, the most powerful Islamic rule at that time (Gallop, 2004: 176). Besides that, Aceh was presumed to be the first territory to forge religious intellectual relations with the Middle East, the centre of Islamic civilization, especially Mecca and Madinah (al-Haramayn). This occurred because Aceh at that time was an important stop-over place for pilgrims from the Malay Archipelago who were travelling to-and-from the Holy Land or al-Haramayn (Muhammad, 2009).

More importantly, the Malay Archipelago was well-known for its rich natural resources that were in great demand at that time. This situation was further substantiated by the fact that the Malay Archipelago was the main port-of-call for ships ferrying raw materials around the world. It was reported that ships from Europe had come to the Malay Archipelago to trade, especially to Aceh. The West had admitted, as commented by a Portuguese officer in Asia named Jorge de Lamos (1585), that if Aceh and the Malay Archipelago were to be colonised, surely Portugal would control the world's trade route;

"Sumatra is such a wonderful thing, and contains such great riches, that I dare to affirm according to what many experienced old men related, whom I over heard when they were conversing with the viceroy of India) that it could well be considered as the equal of England, of which the scriptures speak so highly." "The conquest of Atjeh would give the SpanishPortuguese Crown the economic resources where with to destroy not only 'the Heresiarchs and their followers', but to recover all Christian territory lost to the Muslims (including Jerusalem), and to overthrow the Ottoman Empire".

In reference to the role of Aceh in advocating Islam's political agenda, Aceh is one of the strongest allies of Islam that can stop the expansion of Christianity, which was the main agenda of the Portuguese. The role became more evident after the fall of Melaka to the Portuguese (Rahimin, 2015).

Hence, the Acehnese Sultanate at that time ought to have been able to compete with foreign powers. It was then that Sheikh Shamsuddin Sumatrani was seen to be prominent in the governance of Aceh by becoming a worthy partner to Sultan Iskandar Muda. A large part of the religious intellectual development in Aceh was due to Shamsuddin Sumatrani's high level of dedication towards entertaining and responding to the Sultan's ideas. Yusni Saby stated that Shamsuddin Sumatrani and Hamzah Fansuri played the role of tarekat or Sufi teachers to the Sultan. It was this position that elevated their authority in the Acehnese government.

Shamsuddin Sumatrani was commissioned by Sultan Iskandar Muda as a diplomat of Aceh to meet Sir James Lancaster, who was himself a diplomat representing the British government in 1602. In order to forge international relations, it was proper for the Sultan to appoint Shamsuddin Sumatrani as a diplomat because he was pious and possessed vast knowledge about religion as well as statehood. Moreover, Lancaster had tremendous respect for Shamsuddin Sumatrani (Gazali, 2016). 
INTERNATIONAL JOURNAL OF ACADEMIC RESEARCH IN BUSINESS AND SOCIAL SCIENCES Vol. 8, No. 10, Oct. 2018, E-ISSN: 2222-6990 @ 2018 HRMARS

During the process of diplomatic discourse, Shamsuddin Sumatrani used Arabic because Sir James Lancaster brought along a Jewish translator who was fluent in Arabic as well as being an assistant to General Lancaster. The aim of Sir James Lancaster's visit to Aceh Dar al-Salam was to convey a letter from Queen Elizabeth, the Queen of England (Said, 1981).

Other than the British, relations between the Aceh government during the reign of Sultan Iskandar Muda (1590-1636) and the 'Ottoman Empire had consolidated Aceh's defence system. This materialised when the Sultan of Aceh began to build good relations by sending diplomats to Turkey and brought gifts, such as spices, for the 'Ottoman ruler so that diplomatic ties with Aceh could grow. Eventually, the strategy was successful and the Aceh entourage was well received by the 'Ottoman Caliphate in Turkey (Yakin, 2015: 80). According to H.M. Zainuddin, as quoted by Basri A. Bakar, Aceh's diplomat to Ottoman Turkey during the reign of Sultan Iskandar Muda was Commander (Panglima) Nyak Dum, who was one of Aceh's war Commanders at that time, as well as his entourage (Bakri, 2016).

Next, during the conflict between Darul Islam (DI) or the Islamic Army of Indonesia (TII) and the Indonesian rulers at the beginning of independence, this group emerged in several of the Provinces in Indonesia. They claimed for the formation of an Islamic nation and its separation from Indonesia. In Aceh, this group was led by Teungku Muhammad Daud Beureueh, who was a modernist Ulama. In this case, diplomatic values could be found in the attitudes held by Abuya Sheikh Muhammad Waly al-Khalidy, who was a tasawwuf Ulama and Khalifah Tarekat Naqshabandiyyah in Aceh. A renown Acehnese historian, Prof. Teungku Haji Ali Hasjimi had great respect for him because of his love for his motherland, avoiding strict or firm attitudes when confronting issues on governance while advocating diplomatic measures when solving Aceh's conflicts at that time. His attitudes on diplomacy were appreciated by the rulers so much so that he was one of the Ulama who was invited by President Soekarno to discuss the Aceh issue and Indonesian Muslims, in general (Waly, 1993).

Based on the discussion above, it could be concluded that long ago the Ulama not only played a role from the religious aspect but they were given various duties and functions. The Ulama frequently received recognition from the Sultan for helping out with government duties. The Ulama had indeed played a role at that time but this is not the case now. When referring to Qanun Aceh Nombor 2 Tahun 2009, the role of the Ulama is restricted to functions and duties pertaining to religion only and not anymore to diplomatic duties. This could be because Aceh was no longer a government or country (Nurdin, 2011).

\section{AS A MUFTI}

The glory of the Malay civilization in Aceh was prominent around the $15^{\text {th }}$ to the $17^{\text {th }}$ century. Aceh was presumed to be in command in the East, with the 'Ottoman Caliphate in the West. According to A. H. Johns, Aceh became a renown centre for politics and Islamic studies in the Malay Archipelago in the $17^{\text {th }}$ century. As an Islamic country, innumerable mosques were built, among them was Masjid Bait al-Rahman and Bait al-Musyahadah. In addition, a moderate-sized mosque was built in every village. Many schools and Islamic education centres ('Dayah Cot Kala') were built and students were taught to write and do maths in Arabic. According to Darwis A. Soelaiman, the official language used 
in the Aceh Dar al-Salam Sultanate in the $16^{\text {th }}$ century was Aceh, Malay and Arabic. Moreover, religious life flourished rapidly and Islam became the official religion for the government and a way of life for the Acehnese.

The influence of Islam is reflected in the structure of governance, punishments, legislation, foreign politics as well as the role of the Ulama in governance and education. Aceh also became the centre of activity for writing Malay literature. Scriptures in Arabic, Aceh and Malay in fields such as history, religion and literature were written. Briefly, the writing of scriptures in Jawi was at its pinnacle in Aceh. This is related to the personality of Sultan 'Alauddin Ri'ayat Shah Sayyid Mukammil (1588-1604) and Sultan Iskandar Muda (1607-1636) who truly loved knowledge.

Zakaria Ahmad, in his book Around the Government of Aceh Dar al-Salam: From 1520-1675, stated that Aceh had become a place of focus by Ulama from all over the Islamic world in order to gain the protection of the Sultan. Besides that, Aceh was inhabited by many Ahl al-Bayt ulama. Hamzah Fansuri, Shamsuddin Sumatrani, Nuruddin Raniri, Bukhari Jawhari and 'Abdurrauf Singkili were among the famous Ulama of Aceh. All these ulama were from the Shāfi'i sect and followed the Ahl al-Sunnah Wa al-Jama'ah school of thought (Shahrul, 2014).

The ulama's socio-political commitment was related to the history of Aceh and within a fairly long time, was influenced by Islam. During the successful reign of the Acehnese Islamic Government, the special characteristic that complimented both the strengths of the institution became very meaningful. As mentioned in an Aceh proverb (hadih maja) "Adat Bak Poeteumereuhom, Hukom Bak Syiah Kuala ('Abdurrauf Singkili)", which means, "customary law is determined by the Sultan and religion is determined by the ulama" (Nuraini, 2014).

What the proverb above expressed had indirectly indicated the truth. For example, it was found that during the reign of Sultan 'Alauddin Ri'ayat Shah as the Ruler of Aceh DÉr al-SalÉm at the end of the $16^{\text {th }}$ century (1588-1604M), Hamzah Fansuri was the figure who played an important role in the government. Moreover, he was the Mufti to the government of Aceh Dar al-Salam during the same time. At the same time, he had endeavoured to expand the Tasawwuf Wujudiyyah (Double, 2007).

In addition to implementing the responsibility of a government Mufti, he also carried out dakwah (religious sermons) through poetry that he had written as well as scriptures on Islamic studies. Although his poetries emphasised on a mediocre lifestyle and abstinence from a luxurious life that could lead to deleterious consequences, he still received the recognition and attention from palace authorities. This shows his level of knowledge and personality, which eventually influenced the Sultan (Said, 1981).

Whereas, during the reign of Sultan Iskandar Muda of Aceh Dar al-Salam, the Mufti was Shamsuddin Sumatrani. Due to his vast command of knowledge, he obtained numerous titles. Sultan Shah Alam, who reigned from 1589 to 1604, called Shamsuddin the Sheikh al-Islam. Frederich de Houtman, a Dutch explorer, referred to him as "cheech den oppersten raethsheer van den coninck" 
INTERNATIONAL JOURNAL OF ACADEMIC RESEARCH IN BUSINESS AND SOCIAL SCIENCES Vol. 8, No. 10, Oct. 2018, E-ISSN: 2222-6990 @ 2018 HRMARS

(Advisor Sheikh to His Highness the King). "Aarts Bisschop" (Royal Imam), was the nickname given by John Davis, an English explorer. Sir James Lancaster, a British diplomat, had called him "The Chiefe Bishope or "Chief Imam". As an Ulama, Sufi scholar and philosopher as well as obtaining the full support of Sultan Iskandar Muda, Shamsuddin had greater leeway to expand his teachings until he secured enough influence within the Aceh Dar al-Salam government (Suwondo, 1998).

During the reign of Sultan Iskandar Thani, the Aceh Dar al-Salam government had a Mufti called Sheikh Nuruddin Raniri. He was a khalifah in Tarekat Rifāîyyah and responsible for propagating it to the Malay Archipelago (Majid, 2015: 180-181). His scholarship had attracted the interest of the Orientalists to study the affairs related to this scholar (Hashim, 2008). When he was the Mufti, he delivered a fatwa whereby the teachings of Waldat al-Wujud (Wujudiyyah), which was propagated by Hamzah Fansuri and Shamsuddin Sumatrani, were deviationist teachings and the followers were obliged to repent and if they did not repent, the punishment was death. (Azyumardi, 1995).

After the death of Sultan Iskandar Thani, an interesting situation emerged involving a heated debate about plans to appoint Queen Taj al-'Alam Safiyatuddin Shah as the highest authority in the Aceh Government. The male descendants of the Sultan of Aceh had tried to wrest the seat of the government with the support of the Ulama who had stated that a woman cannot become a King because that contradicts syariat Islam. They argued that women could not become the imam for prayers where men are the ma'mum. Hence, women are not allowed to be the Wali al-Am. After reading and understanding the ideas that contradicted and the political situation in Aceh, as mentioned earlier, Sheikh 'Abdurrauf al-Singkily was finally able to manage and appease the unrest by having a meeting between the two parties. Sheikh 'Abdurrauf al-Singkily was of the opinion that Taj al-'Alam Safiyatuddin Shah could be appointed as the Sultanah, to replace her husband, Iskandar Thani. However, the appointment must be limited to determining the criteria for marriage, talaq, fasakh, while other matters related to religious law was still in the hands of the Ulama, namely Qadi al-Malik al- 'ódil (Wirianto, 2013).

Thus, with the wisdom of Sheikh 'Abdurrauf Singkili, political stability and religious life gradually returned. As an appreciation, Sultanah Taj al-'Alam Safiyatuddin Shah had inaugurated Sheikh 'Abdurrauf Singkili as the State Mufti as well as her advisor. Actually, the offer to become the State Mufti was initially declined by Sheikh 'Abdurrauf Singkili because he had no ambition to helm that position. However, after considering national interest and societal welfare, he eventually succumbed to the wishes of Sultanah Taj al-'Alam Safiyatuddin Shah. The Sultanah requested Sheikh 'Abdurrauf Singkili to write a scripture on fiqh entitled, Mir'at al-Tullab (Wirianto, 2013).

Presently, the role of the Mufti is implemented by the "Majelis Permusyawaratar Ulama" (MPU), which is an institution made up of Ulama from Aceh (Nurdin, 2012). This institution is headed by a capable Ulama who is chosen during a meeting of the Ulama. The head of the MPU was again lead by Prof. Dr Tgk. Hj. Muslim Ibrahim for a period between 2017-2022. He stated his desire to improve efforts to assimilate syariat Islam in Aceh. According to him, all this while syariat Islam in Aceh was only associated with punishments, although the educational aspect was very important in 
INTERNATIONAL JOURNAL OF ACADEMIC RESEARCH IN BUSINESS AND SOCIAL SCIENCES Vol. 8, No. 10, Oct. 2018, E-ISSN: 2222-6990 ㄷ 2018 HRMARS

Islam (Bakri, 2017). In addition, the role of MPU involved three aspects, which is to consider the policies of the Aceh Rulers, to drive society and to form fatwas (Bakri, 2017).

The harmonious relationship between the Ruler and the Ulama was an important key for summarising strategic steps involved in social empowerment. Yahya bin Jusoh quoted from a manuscript entitled Majelis Aceh or Adat Aceh, whereby, "When the King respects all the pandita (Ulama), then religion flourishes and when the King only respects the ministers, the people become fearful of the King's power due to the actions of the ministers".

Yahya bin Jusoh explained in greater detail that the poem (bait) above reflects the basis of the syura's function (negotiations) among high-ranking government leaders. The syura in a country (government) that is centred on Islamic law is an element of an identity. An encounter or a meeting is a form of negotiation, which over time changes to become a custom (adat) that reflects the strength of the relationship between two parties, namely the Ulama and umara. The harmony between the umara and the Ulama could confidently build an Acehnese society that is well-being and prosperous (Gazali, 2015).

\section{CONCLUSION}

Based on the arguments above, it could be concluded that Acehnese tasawwuf ulama were not only Sufis, but also entrusted with the position of a government mufti. Moreover, it could be observed that all Aceh Sultans who became Muftis were tasawwuf ulama.

\section{ACKNOWLEDGEMENT}

This article is part of a research fund sponsored and managed by the Center for Research and Innovation (RMIC), Sultan Zainal Abidin University (UniSZA), Gong Badak Campus 21300 Kuala Nerus, Terengganu, Malaysia.

\section{REFERENCES}

Rahimin, A.A.R. (2015). Relasi Aceh dan Turki Dalam Islamisasi Dunia Melayu: Suatu Analisis. Kontekstualita, 30(1): 25-47.

Abidin, A.Z. (1975). Konsepsi Negara Bermoral Menurut Imam Al Ghazali. Jakarta: Bulan Bintang.

Shahrul, A.N. (2014). Impak Dakwah Kitab Taj al-Salatin Kepada Masyarakat Melayu di Aceh. Selangor: UKM, Pusat Kajian Orang Asli dan Pribumi.

Shahrul, A.N. (2012). Pemikiran Politik Islam Di Aceh Pada Abad Ke 17 M: Kajian Perbandingan Antara Kitab Taj al-Salatin Sulalah al-Salatin Dan Bustan al-Salati. (PhD Thesis) Universiti Kebangsaan Malaysia.

Azyumardi. A. (1995). Jaringan Ulama Timur Tengah dan Kepulauan Nusantara Abad XVII dan XVIII. Bandung: Mizan.

Bakri. (2017). Muslim Ibrahim Pimpin MPU Aceh. Serambi Indonesia.

Hashim, J. (2008). Kitab al-Sirat al-Mustaqim Oleh Shaykh Nur al-Din al-Raniry: Satu Sorotan. Jurnal Fiqh, 5: 97-215.

Double, A.K. (2007). Islam Nusantara Cet. I. Yogyakarta: Pustaka Book Publisher. 
INTERNATIONAL JOURNAL OF ACADEMIC RESEARCH IN BUSINESS AND SOCIAL SCIENCES

Vol. 8, No. 10, Oct. 2018, E-ISSN: 2222-6990 @ 2018 HRMARS

Dzulhadi, Q.N. (2015). Islam Sebagai Agama dan Peradaban. Jurnal Tsaqafah, 11 (1): 151-168.

Gallop, A. (2004). The Ottoman influences in the seal of Sultan Alauddin Riayat Shah of Aceh (r.15891604). Indonesia and the Malay World. 32(93):176-190.

Gazali. (2016). Interelasi Umara dan Ulama Dalam Menata Sosio Keagamaan di Aceh Darussalam Era

Sultan Iskandar Muda 1607-1636. (Tesis Magister).UIN Syarif Hidayatullah.

Hasan, F. (2017). Irwandi Silaturrahmi Ke Rumah Abu Tu Min. Serambi Indonesia.

Hidayat, W. (2017). Tasawuf Akhlaqi Abu Hamid al-Ghazali (Study Atas Kitab Kimiya' al-Sa'adah).

(Tesis Master). UIN Syarif Hidayatullah, Jakarta.

Kansil C.S.T. (2008). Hukum Diplomatik: Dalam Kerangka Studi Analisis. Jakarta: Rajawali Pers.

Majid, A. (2015). Karakteristik Pemikiran Islam Nur ad-Din al-Raniry. Jurnal Substantia, 17(2): 179190.

Muhammad, A. (2009). Peranan Ulama Dalam Memartabatkan Tamaddun Islam Di Nusantara: Tumpuan Terhadap Abdur Rauf Singkel. Jurnal al-Tamaddun. 4:81-98.

Nasar, M.F. (1996). Biografi dan Pemikiran. Jakarta: Gema Insani Press.

Salmah, J.N.M. (2015). Strategi Diplomatik Bervariasi Suatu Kearifan Lokal Dalam Pemerintahan Kesultanan Melayu. International Journal of the Malay World and Civilisation (Iman) 3(2): 79-93.

Nuraini. (2014). Potret Islam Tradisional “Dayah Dan Ulama Di Aceh Abad Ke-20” Dalam Perspektif Sejarah. Jurnal Mudarrisuna, 4(2): 249-288.

Nurdin, A. (2012). Reposisi Peran Ulama Dalam Penerapan Syari'at Islam Di Aceh. Unimal, Al-Qalam, 18(1): 54-65.

Pulungan, J.S. (1995). Fiqih Siyasah. Jakarta: Lembaga Studi Islam dan Kemasyarakatan.

Rahayu, I.S. (2015). Baldatun Tayyibah: Model Kesultanan Melayu Nusantara. Selangor: Persatuan Ulama Malaysia.

Rahman, F. (1984). Islam, Terj. Ahsin Mohammad. Bandung: Pustaka.

Said, H.M. (1981). Aceh Sepanjang Abad, Jil. 1. Medan: PT. Percetakan dan Penerbitan Waspada.

Suryo, K.S. (2008). Hukum Diplomatik: Dalam Kerangka Studi Analisis. Jakarta: Rajawali Press.

Suwondo, T. (1998). Syamsuddin as Sumatrani (Riwayat, Karya, Ajaran, Kecaman dan Pembelaannya).

Pangsura: Jurnal Pengkajian dan Penelitian Sastra Asia Tenggara, 7(4): 49-62.

TriPutra, R.S. (2015). Profil dan Hirarki Ulama. Adabiyah: Jurnal Pendidikan Islam, 1(1): 15-28.

Waly, M. (1993). Ayah Kami: Maulana Haji Muhammad Waly al-Khalidy Singapore: Jew Printers \& Binders PTE LTD.

Widagdo, S. (2008). Hukum Diplomatik dan Konsuler, (Buku Ajar untuk Mahasiswa). Malang: Banyu Media Publishing.

Wirianto, D. (2013). Meretas Konsep Tasawuf Syeikh Abdurrauf al-Singkily. Islamic Movement Journal, 1(1): 109-123.

Yakin, A.U. (2015). Islamisasi dan Syari'atisasi Samudera-Pasai Abad 14 Masehi. UIN Syarif Hidayatullah, Islamica, 9(2): 272-273.

Abdullah, M.S.Y. (2008). Retrosfektif Peranan Ulamak Dalam Pembangunan Rohani di Aceh. Selangor: UKM. 